Acta Theriologica 45, Suppl. 1: 19-26, 2000.

PL ISSN 0001-7051

\title{
Chromosome races of the common shrew Sorex araneus in the Ural Mts: a link between Siberia and Scandinavia?
}

\author{
Andrei V. POLYAKOV, Jan ZIMA*, Jeremy B. SEARLE, \\ Pavel M. BORODIN and Tatiana LADYGINA
}

\begin{abstract}
Polyakov A. V., Zima J., Searle J. B., Borodin P. M. and Ladygina T. 2000. Chromosome races of the common shrew Sorex araneus in the Ural Mts: a link between Siberia and Scandinavia? [In: Evolution in the Sorex araneus group: Cytogenetic and molecular aspects. J. B. Searle and J. M. Wójcik, eds]. Acta Theriologica 45, Suppl. 1: $19-26$.

Cytogenetic analysis of natural populations of the common shrew Sorex araneus Linnaeus, 1758 over a large area in the vicinity of the Ural Mts revealed the presence of four distinct chromosome races (Yuryuzan, Sok, Serov and Novosibirsk). Each of them differed from a neighbouring race by a single whole arm reciprocal translocation. The two races on the western slope of the Urals (Yuryuzan and Sok) were identical in karyotype to races which have already been reported from Finland (Ilomantsi and Kuhmo). These findings indicate that, during the last glaciation, the Urals could have been a refugium for a group of related chromosome races which are currently distributed in this mountain range and in Finland, respectively.

Institute of Cytology and Genetics, Russian Academy of Sciences, Lavrentiev ave. 10 , Novosibirsk630090, Russia, e-mail: polyakov@bionet.nsc.ru, borodin@bionet.nsc.ru (AVP, PMB, TL); Institute of Vertebrate Biology, Academy of Sciences of the Czech Republic, Květná 8, CZ-603 65 Brno, and Department of Zoology, Faculty of Science, Charles University, Viničná 7, CZ-128 44 Praha, Czech Republic, e-mail: jzima@brno.cas.cz (JZ); Department of Biology, University of York, P.O. Box 373, York YO10 5YW, U.K., e-mail: jbs3@york.ac.uk (JBS)
\end{abstract}

Key words: Sorex araneus, karyotypic variation, raciation, evolution

\section{Introduction}

The common shrew Sorex araneus Linnaeus, 1758 displays remarkable chromosomal variation, largely attributable to Robertsonian rearrangements (ie centric fusions, in each of which two acrocentric chromosomes join to give rise to a metacentric chromosome). It is believed that the ancestral karyotype of the common shrew was composed of acrocentric chromosomes and that karyotype evolution has proceeded in the direction from high to low chromosome numbers. Different sets of Robertsonian fusions have become fixed in different parts of the species range leading to racial differentiation (Searle 1984, Volobouev 1989, Zima 1991, Wójcik 1993, Searle and Wójcik 1998). More than 50 chromosome races have

\footnotetext{
* Corresponding author
} 
already been described (Zima et al. 1996) and the actual number of distinct races remains open.

It is thought that arm combinations in the metacentrics of common shrews and other small mammals can be modified by whole arm reciprocal translocations, WARTs (Winking 1986, Halkka et al. 1987, Searle and Wójcik 1998). In the common shrew there are cases where chromosome races form a series (cascade) that can most simply be explained by WARTs. Such cascades of WARTs have been postulated in Finland (Halkka et al. 1987, 1994) and Sweden (Fredga 1996). Furthermore, Halkka et al. (1994) suggested a relationship, based on WARTs, between the Finnish and Siberian chromosome races of common shrews. In particular, to link the Novosibirsk race with the Finnish group of races, the authors predicted the existence of an intermediate hypothetical 'Old-Northern race'. This race was recently found in the eastern Ural Mts and described by Polyakov et al. (1997) as the 'Serov race'. This finding provided good evidence for the Siberian-Finnish connection and stimulated our present study in the chromosome geography of the common shrew in the Ural Mts.

\section{Material and methods}

Common shrews were collected with live traps at eight localities in the heart of the Ural Mts and on their eastern and western periphery, in 1995 and 1996 (Table 1, Fig. 1). Five sites were scattered from the south to the north on the eastern periphery of the Urals (Kedrovy, Serov, the Techa river previously designated as Chelyabinsk by Polyakov et al. 1997, Kurgan and the Miass river) and two sites on the western periphery of the Urals (the Usen' river in the Bugul'minsko-Belebeevskaya highland and the Sok river). The remaining collecting site, Yuryuzan', was situated on the top of the main ridge of the Urals. Four sites (the Miass river, Yuryuzan', the Usen' and the Sok rivers) were situated along a latitudinal line crossing the southern Urals from the east to the west, at a distance of 200-300 km from each other.

Chromosome spreads were made in the field from bone marrow by the method used at the Institute of Cytology and Genetics, Novosibirsk (Král and Radjabli 1974, Polyakov et al. 1997). G-band staining was conducted in the laboratory according to Radjabli and Kryukova (1973). The chromosome nomenclature follows Searle et al. (1991).

Table 1. Karyotypes of shrews found in different localities in the vicinity of the Ural Mts. M - male, F female.

\begin{tabular}{|c|c|c|c|c|c|c|}
\hline No. & Site & Coordinates & $\begin{array}{l}\text { Individuals } \\
\text { examined }\end{array}$ & Karyotype & Race & Reference \\
\hline 1 & Kedrovy & $61^{\circ} 28^{\prime} \mathrm{N}, 68^{\circ} 14^{\prime} \mathrm{E}$ & $2 \mathrm{M}+2 \mathrm{~F}$ & $g o, h n, i p, j l, k m, q r$ & Serov & this paper \\
\hline 2 & Serov & $59^{\circ} 50^{\prime} \mathrm{N}, 60^{\circ} 22^{\prime} \mathrm{E}$ & $2 \mathrm{M}+3 \mathrm{~F}$ & $g o, h n, i p, j l, k m, q r$ & Serov & Polyakov et al. 1997 \\
\hline 3 & Techa & $55^{\circ} 59^{\prime} \mathrm{N}, 61^{\circ} 15^{\prime} \mathrm{E}$ & $5 \mathrm{M}+2 \mathrm{~F}$ & go, hn, ip, jl, km, qr & Serov & Polyakov et al. 1997 \\
\hline \multirow[t]{2}{*}{4} & Kurgan & $55^{\circ} 30^{\prime} \mathrm{N}, 65^{\circ} 20^{\prime} \mathrm{E}$ & $2 \mathrm{M}+2 \mathrm{~F}$ & $g o, h n, j l, i k / i p / m p / k m, q r$ & hybrid & this paper \\
\hline & & & $2 \mathrm{M}$ & $g o, h n, i k, j l, m p, q r$ & Novosibirsk & Polyakov et al. 1996 \\
\hline 5 & Miass & $55^{\circ} 15^{\prime} \mathrm{N}, 61^{\circ} 50^{\prime} \mathrm{E}$ & $1 \mathrm{M}$ & go, hn, ip,jl, km, qr & Serov & this paper \\
\hline 6 & Yuryuzan' & $54^{\circ} 50^{\prime} \mathrm{N}, 58^{\circ} 20^{\prime} \mathrm{E}$ & $1 \mathrm{M}+1 \mathrm{~F}$ & $g o, h n, i p, j l, k r, m q$ & Yuryuzan & this paper \\
\hline 7 & Usen' & $54^{\circ} 30^{\prime} \mathrm{N}, 54^{\circ} 00^{\prime} \mathrm{E}$ & $2 \mathrm{M}$ & go, $h n, i p, j l, k q, m r$ & Sok & this paper \\
\hline 8 & Sok & $53^{\circ} 35^{\prime} \mathrm{N}, 50^{\circ} 30^{\prime} \mathrm{E}$ & $1 \mathrm{M}+1 \mathrm{~F}$ & $g o, h n, i p, j l, k q, m r$ & Sok & this paper \\
\hline
\end{tabular}




\section{Results and discussion}

The results of this survey are given in Table 1, which contains the localities with their coordinates, the number and sex of all the common shrews studied, their karyotypes and the respective chromosome races. Each site is given the same number as in Fig. 1.

The Serov race is characterised by the chromosome arm composition go, $h n$, ip, $k m, q r$ (Polyakov et al. 1997). It was found in four out of the five sites located in the eastern Urals. The fifth site, Kurgan at the right bank of the Tobol river, was apparently within a hybrid zone between the Serov and Novosibirsk races. Two out of the six shrews examined in this site had a karyotype of the Novosibirsk race (go, $h n, i k, m p, q r$ ), and the karyotypes of the other four individuals corresponded to F1 hybrids between the Serov and Novosibirsk races (go, hn, ik/ip/mp/km, qr). An electron microscopic analysis of the surface spread spermatocytes of a hybrid male

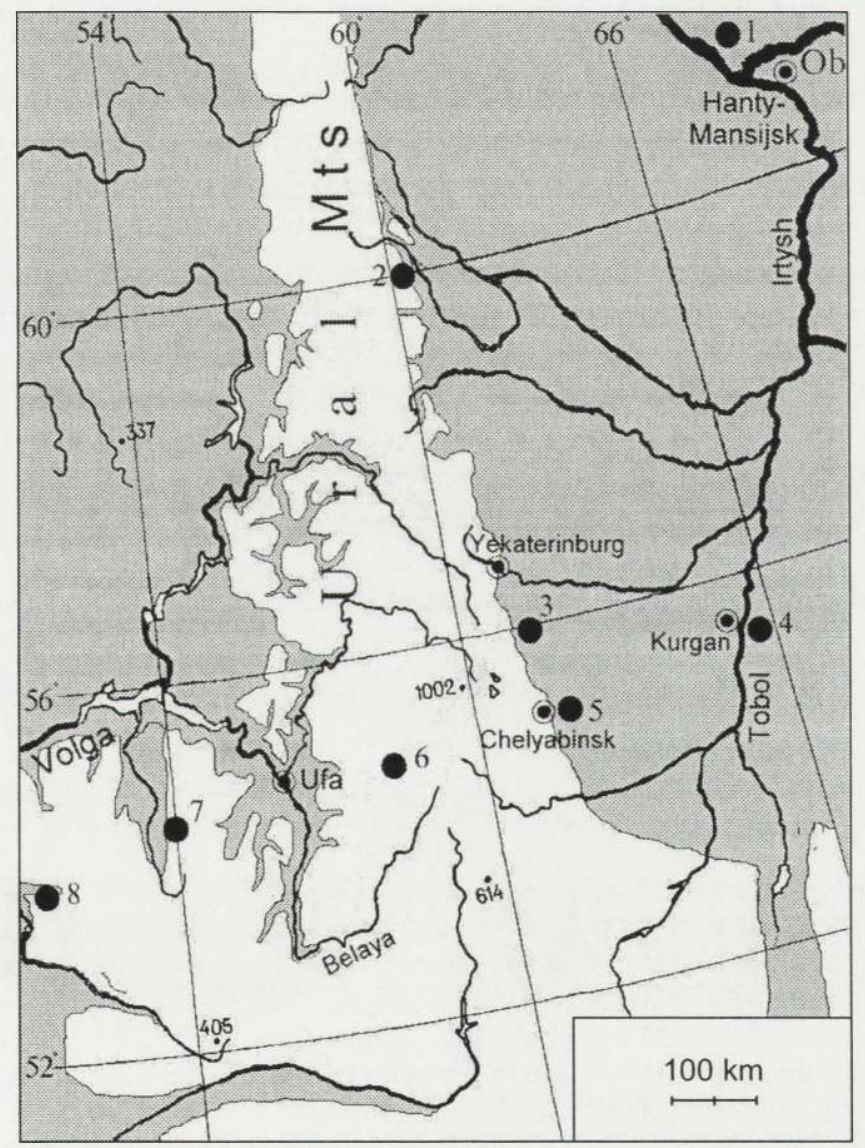

Fig. 1. Location of investigated sites. See Table 1 for numbering of the sites. 
revealed a regularly paired autosomal quadrivalent. Mature sperm were abundant in these spreads (Borodin et al. 1997). This indicates that the hybrid had a normal meiosis and was likely to have been fertile.

At all the other sites examined between the Urals and the Ob river, the Novosibirsk race was found (Polyakov et al. 1996). Thus we may consider the Tobol and Irtysh rivers as a probable border between the Serov and Novosibirsk races. The southern borders of the Serov race are close to the southern margins of the distribution range of Sorex araneus, because southward of the Tobol and Miass rivers, mixed forests are substituted by very dry, treeless steppe. Kedrovy, the northernmost of the localities studied, is probably close to the northern extreme of the continuous range of the common shrew (Corbet 1978).

At Yuryuzan', $220 \mathrm{~km}$ west of the Miass river, where the Serov race was present, we found two shrews which differed from that Serov race by two metacentrics that could have arisen by a single WART. They had a karyotype containing the metacentrics go, $h n, i p, k r, m q$. A representative karyotype of a shrew from Yuryuzan' is shown in Fig. 2. This chromosome constitution also characterises a race in Finland described by Halkka et al. (1987) as the 'Ilomantsi race'. The area between the two regions where this karyotype has been found, separated by a distance of more than $2000 \mathrm{~km}$, has not been studied in sufficient detail. However, given that a continuous range of this size would be exceptional for a chromosome race of the common shrew (Searle and Wójcik 1998), we tentatively describe the population from Yuryuzan' as a new race. This follows the rule developed for the common shrew, that disjunct populations with the same karyotype should be

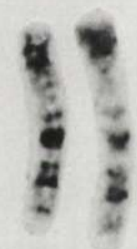

a $\mathbf{f}$

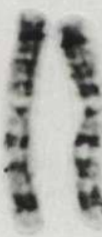

b c

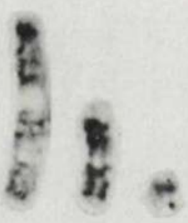

$X^{\prime} Y_{2} Y_{1}$

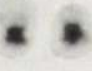

tu
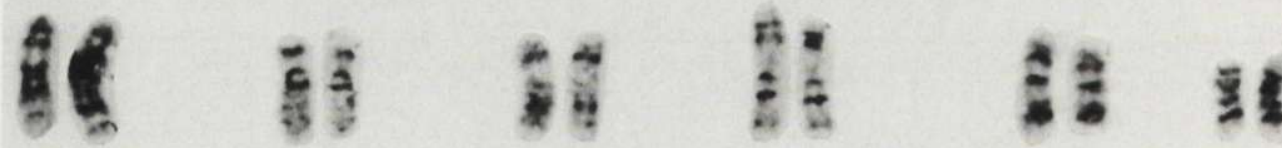

g 0

h n

i p

j I

k r

$\mathrm{m} q$

Fig. 2. G-banded karyotype of a male from Yuryuzan'. 
considered distinct chromosome races (Hausser et al. 1994). The details of the proposed new race are as follows:

Yuryuzan race $(\mathrm{Yu})$

$\mathrm{XX} / \mathrm{XY}_{1} \mathrm{Y}_{2} a f, b c, g o, h n, i p, j l, k r, m q, t u$

Type locality: Yuryuzan', Ural Mts, Russia, $54^{\circ} 50^{\prime} \mathrm{N}, 58^{\circ} 20^{\prime} \mathrm{E}$

Distribution: The type locality

The range of the Yuryuzan race appears to be narrow, at least in the south of the Urals. Just $250 \mathrm{~km}$ to the west from Yuryuzan', we trapped two animals at the Usen' river which had karyotypes that differed from the Yuryuzan race by two metacentrics that could have resulted again from a single WART. They had a karyotype with the metacentrics go, $h n, i p, k q, m r$. The same karyotype was found in a site by the Sok river, situated $250 \mathrm{~km}$ west of the Usen' river (Fig. 3). This chromosome combination is characteristic for another race from Finland: the 'Kuhmo race' (Halkka et al. 1974). Again, given the distances involved, it appears unlikely that the sites in the Urals occur within the continuous distribution range of the Kuhmo race, although further sampling would be desirable to prove the point. Therefore, we tentatively suggest that the populations recorded in the western Urals are a new geographically disjunct chromosome race:

Sok race (So)

$\mathrm{XX} / \mathrm{XY}_{1} \mathrm{Y}_{2} a f, b c, g o, h n, i p, j l, k q, m r, t u$

Type locality: Sok river, Ural Mts, Russia, $53^{\circ} 35^{\prime} \mathrm{N}, 50^{\circ} 30^{\prime} \mathrm{E}$

Distribution: The area between the Sok and Usen' rivers, western slopes and foothills of the Ural Mts, Russia

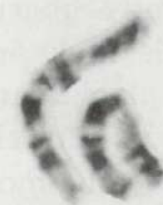

af

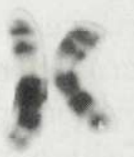

g 0

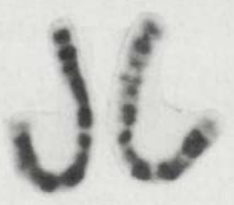

b c

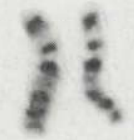

$\mathrm{hn}$

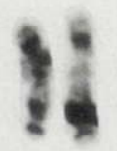

i $p$

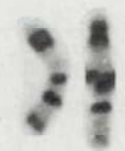

j 1

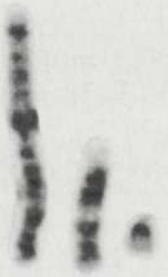

$X \quad Y_{2} Y_{1}$

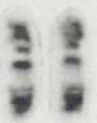

k q

m r

Fig. 3. G-banded karyotype of a male from Sok river. 
It is interesting that the karyotype of the Yuryuzan race is equidistant from the karyotypes of the Serov and Sok races. In both cases only a single WART is necessary to derive one race from another. The six animals studied of the Sok and Yuryuzan races were all-metacentric homozygotes. On the other hand, the Kuhmo and Ilomantsi races show a relatively high level of chromosome polymorphism, involving all the discriminating chromosomes: $i, k, m, p, q, r$ (Halkka et al. 1974, 1987).

The simple idea of a WART cascade has proven its value when it allowed Halkka et al. (1994) to predict the existence of the hypothetical Old Northern race somewhere between eastern Finland and western Siberia, which in fact has been found in the eastern side of the Urals and described by Polyakov et al. (1997) as the Serov race. What was difficult to predict, however, was the presence of two Finnish races in the western Urals. Whereas two Siberian races, Novosibirsk and Tomsk, occupy huge areas covering hundreds of thousands of square kilometers (Polyakov et al. 1996), this is unlikely for the two pairs of "Finnish-Ural" races. The latter races apparently have a mosaic distribution pattern, and their ranges seem to be interspersed among populations belonging to other races in both the areas concerned. However, the possibility that the twin "Finnish-Ural" races still occupy continuous ranges cannot be definitively disregarded without obtaining more data on the chromosomal constitution of populations occurring between Scandinavia and the Urals. If such a situation is proved, the racial nomenclature should be changed according to the priority rule (Hausser et al. 1994).

In our previous paper (Polyakov et al. 1996), we suggested that the Novosibirsk race originated in the Ural Mts and dispersed from the glacial refugium in a south-eastern direction. Our recent finding of a cluster of closely related races in the south-western Urals may indicate that this region represented a refugial area also for other ancestral populations which populated successively not only Siberia, but Scandinavia as well. The two races found in the western Urals (Sok and Yuryuzan) may be considered as evolutionary relics of the late glacial and postglacial period. It is interesting that the Kuhmo race (the Finnish twin of the Sok race) occupies a relatively large range in Finland, and is considered the most ancient among the Finnish races (Halkka et al. 1987). Therefore it seems reasonable to suggest that one of the "Finnish-Ural" races survived the glacial period in a refugium in the Urals and then gave rise to others which are currently distributed around the Urals. During postglacial colonisation from the Urals, the Sok and Yuryuzan races might have expanded their ranges to the northwest and given rise to the branch of races in Finland. In fact, this Finnish branch may currently be found even further north-east than the Kuhmo race. The northernmost Finnish Savukovski race, which was previously included in the Kuhmo race (Halkka et al. 1987), is adjacent to the easternmost Swedish Abisko race. These two races differ from each other by a single WART only, and Fredga (1996) suggested that a further cascade of WARTs may link together all the Swedish and Danish races from Abisko to Sjaelland. 
The other possible explanation of the existence of identical chromosome races in Scandinavia and the Urals is an independent origin of the same chromosomal constitution in the two areas. This possibility cannot be rejected without further studies with genic markers.

Acknowledgements: We thank M. Bochkarev for invaluable help in collecting shrews. The assistance of J. Piálek and M. Homolka in the final preparation of figures is appreciated. We are obliged to K. Fredga for his helpful comments on the earlier draft of this manuscript. The study was supported by grants from INTAS (No. 93-1463), Russian Foundation for Basic Research (No. 95.04-12698a and 96-15-97738) and in part by the Ministry of Education of the Czech Republic (No. VS97102).

\section{References}

Borodin P. M., Ladygina T. Yu., Polyakov A. V. and Rogatcheva M. B. 1997. Pairing of chromosomes in Robertsonian heterozygotic shrews (Sorex araneus and Suncus murinus). Doklady Rossiïskoï Akademii Nauk 356: 132-134. [In Russian with English summary]

Corbet G. B. 1978. The mammals of the Palaearctic region: a taxonomic review. British Museum (Natural History), London: 1-314.

Fredga K. 1996. The chromosome races of Sorex araneus in Scandinavia. Hereditas 125: 123-135.

Halkka L., Halkka O., Skarén U. and Söderlund V. 1974. Chromosome banding pattern in a polymorphic population of Sorex araneus from northeastern Finland. Hereditas 76: 305-314.

Halkka L., Kaikusalo A. and Vakula N. 1994. Revision of Sorex araneus L. chromosome nomenclature, and race $\mathrm{N}$ new to Finland. Annales Zoologici Fennici 31: 283-288.

Halkka L., Söderlund V., Skarén U. and Heikkilä J. 1987. Chromosomal polymorphism and racial evolution of Sorex araneus L. in Finland. Hereditas 106: 257-275.

Hausser J., Fedyk S., Fredga K., Searle J. B., Volobouev V., Wójcik J. M. and Zima J. 1994. Definition and nomenclature of the chromosome races of Sorex araneus. Folia Zoologica 43, Suppl. 1: 1-9.

Král B. and Radjabli S. I. 1974. Banding patterns and Robertsonian fusions in the western Siberian population of Sorex araneus (Insectivora, Soricidae). Folia Zoologica 23: 217-227.

Polyakov A. V., Borodin P. M., Lukáčová L., Searle J. B. and Zima J. 1997. The hypothetical Old-Northern chromosome race of Sorex araneus found in the Ural Mts. Annales Zoologici Fennici 34: 139-142.

Polyakov A. V., Borodin P. M., Volobouev V. T. and Searle J. B. 1996. Karyotypic races of the common shrew (Sorex araneus) with exceptionally large ranges: the Novosibirsk and Tomsk races of Siberia. Hereditas 125: 109-115.

Radjabli S. I. and Kryukova E. P. 1973. A comparison of banding patterns in two hamster species Cricetulus barabensis and C. griseus. Citologiya (Leningrad) 15: 1527-1531. [In Russian with English summary]

Searle J. B. 1984. Three new karyotypic races of the common shrew Sorex araneus (Mammalia: Insectivora) and a phylogeny. Systematic Zoology 33: 184-189.

Searle J. B., Fedyk S., Fredga K., Hausser J. and Volobouev V. T. 1991. Nomenclature for the chromosomes of the common shrew (Sorex araneus). Mémoires de la Société Vaudoise des Sciences Naturelles 19: 13-22.

Searle J. B. and Wójcik J. M. 1998. Chromosomal evolution: the case of Sorex araneus. [In: Evolution of shrews. J. M. Wójcik and M. Wolsan, eds]. Mammal Research Institute, Polish Academy of Sciences, Białowieża: 219-268.

Volobouev V. T. 1989. Phylogenetic relationships of the Sorex araneus-arcticus species complex (Insectivora, Soricidae) based on high-resolution chromosome analysis. Journal of Heredity 80: 284-290.

Winking H. 1986. Some aspects of Robertsonian karyotype variation in European wild mice. Current Topics of Microbiology and Immunology 127: 68-74. 
Wójcik J. M. 1993. Chromosome races of the common shrew Sorex araneus in Poland: a model of karyotype evolution. Acta Theriologica 38: 315-338.

Zima J. 1991. Is the trend toward low $2 \mathrm{Na}$ numbers inescapable for Sorex araneus populations? Mémoires de la Société Vaudoise des Sciences Naturelles 19: 63-71.

Zima J., Fedyk S., Fredga K., Hausser J., Mishta A., Searle J. B., Volobouev V. T. and Wójcik J. M. 1996. The list of the chromosome races of the common shrew (Sorex araneus). Hereditas 125: 97-107.

Received 30 September 1999, accepted 26 January 2000. 